\title{
PERANCANGAN DAN IMPLEMENTASI POINT OF SALE SYSTEM MENGGUNAKAN BAHASA PEMPROGRAMAN VISUAL BASIC.NET 2013 DAN DATABASE SQL SERVER 2012 PADA TOKO RAFADEL
}

\author{
Mardalius $^{1)}$ \\ Sistem Informasi, UPI "Y P T K”, Padang \\ mardalius18@gmail.com
}

\begin{abstract}
Abstrak : Komputer telah menjadi alat bantu utama dalam tiap kegiatan manusia. Tidak hanya untuk aplikasi bisnis, namun juga dalam kegiatan sehari-hari. Hal ini menunjukkan bagaimana komputer telah menjadi bagian dari evolusi manusia.

Tujuan skripsi ini adalah mengembangkan point of sale system pada Toko Rafadel yang berbasis desktop. System informasi ini dapat mempermudah, mempercepat dan mengurangi tingkat kesalahan dalam pengelolaan baik data penjualan, pembelian, stok, dan laporan. Adapun permasalahan pada Toko Rafadel adalah bagian penjualan yang masih sulit dalam mengelola transaksi dan informasi data stok barang yang tidak akurat.

Dalam mengembangkan point of sale system digunakan metodologi Iterasi (Iterative). Dalam metodologi ini terdapat enam tahapan, yaitu: survei sistem, pada tahapan ini dilakukan pengumpulan data terkait dengan poin of sale system yang ada dengan cara melihat secara langsung cara kerja (observasi) dan wawancara guna mengetahui permasalahan yang dihadapi. Tahapan kedua, yaitu tahapan analisis pada tahapan ini hasil identifikasi masalah selanjutnya di klasifikasikan menggunakan kerangka dan untuk menjelaskan kebutuhan sistem yang akan dikembangkan menggunakan aliran sistem informasi. Tahap yang ketiga yaitu desain sistem menggunakan ERD dan DFD. Selanjutnya tahap keempat pembuatan sistem, penulis menggunakan Microsoft Visual Basic.Net 2013 dan Microsoft Sql Server 2012 sebagai database dan pada tahap kelima yaitu implementasi sistem, Tahapan yang terakhir yaitu pemeliharan.

Hasil rancangan sistem ini ditujukan untuk mempermudah pihak toko dalam melakukan pengelolaan data penjualan, pembelian, stok dan laporan.
\end{abstract}

Kata kunci : Point Of Sale System, Microsoft Visual basic.Net 2013, Microsoft Sql Server 2012 
Abstract : Computers have become a major tool in every human activity. Not only for business applications, but also in daily activities. It shows how computers have become a part of human evolution.

The purpose of this paper is to develop a point of sale system on the desktopbased Rafadel Stores. System information can simplify, accelerate and reduce the error rate in the management of both data sales, purchasing, inventory, and reporting. The problems on store sales Rafadel is still difficult to manage transactions and inventory data information that is not accurate.

In developing point of sale system used methodology iteration (Iterative). In this methodology, there are six stages, namely: survey system, at this stage of data collection associated with point of sale systems that exist in a way to see firsthand how the (observation) and interviews in order to know the problems faced. The second stage, ieat this stage of the analysis stage of problem identification results further classified using the framework and to explain the system needs to be developed using the flow of information systems. The third stage is the design of systems using the ERD and DFD. The next stage

Fourth-making system, the author uses Microsoft Visual Basic.Net 2013 and Microsoft Sql Server 2012 as the database and the fifth stage is the implementation of the system, the latter stages, namely maintenance

The design of this system is intended to simplify the management of data stores in conducting the sale, purchase, stock and reports.

Keywords: Point Of Sale System, Microsoft Visual basic.Net 2013, Microsoft Sql Server 2012 


\section{PENDAHULUAN}

\subsection{Latar Belakang Permasalahan}

Dalam dunia perdagangan seperti saat ini, iklim persaingan semakin ketat, Penyajian informasi yang akurat, cepat dan tepat adalah modal utama dalam menghadapi persaingan. Perkembangan ilmu pengetahuan dan tekhnologi telah memperlihatkan perkembangan yang sangat pesat untuk dapat digunakan disemua bidang. Dunia elektronik telah menghasilkan peralatan yang sangat canggih yaitu komputer, dimana komputer mempunyai banyak kegunaan dan kepraktisan kerja yang sangat tinggi untuk mengolah data yag rumit dan dalam jumlah yang banyak.

Suatu usaha yang ingin bersaing dan mengejar keuntungan yang besar, maka komputer merupakan alat bantu yang sangat bermanfaat dalam proses kegiatan perusahaan, termasuk proses penyediaan informasi. Informasi merupakan sumber data yang diperlukan oleh berbagai pihak di perusahaan, baik pihak intern maupun pihak ekstern perusahaan.

Begitu juga dengan Toko Rafadel, perusahaan ini bergerak di usaha dagang yang terletak di kota Padang. Setiap harinya perusahaan ini dapat mencatat banyak transaksi penjualan maupun pembelian, Sistem transaksi penjualan dan pembelian barang pada toko rafadel ini masih dilaksanakan secara manual sehingga menyulitkan untuk mengetahui laporan penjualan, laporan pembelian, dan persediaan barang. Informasi mengenai sistem persediaan ini sangat penting karena proses pembelian maupun penjualan berawal dari sistem ini, untuk itulah sangat diperlukan informasi yang akurat mengenai sistem transaksi pada toko rafadel ini. Dan untuk membantu menciptakan suatu sistem transaksi yang lebih tepat, cepat dan akurat, maka penulis berkeinginan untuk menuangkan permasalahan ini menjadi sebuah karya ilmiah dalam bentuk skripsi dengan memilih Visual Basic.Net sebagai bahasa pemrograman dan Database SQL Server 2012 sebagai tempat penyimpanan data yang diterapkan dengan mengambil judul:

“ Perancangan Dan Implemestasi Point Of Sale System Secara User Friendly Menggunakan Bahasa Pemprograman Visual Basic.Net 2013 Dan Database SQL Server 2012 Pada Toko Rafadel ".

\subsection{Perumusan Masalah}

Berdasarkan latar belakang permasalahan diatas maka masalah penelitian dirumuskan sebagai berikut:

1. Sistem komputer yang belum diaplikasikan secara optimal seperti penggunaan komputer hanya sebagai media pengetikan saja dan belum adanya system dari pengolahan data penjualan .

2. Sistem pengolahan data yang masih secara manual sehingga menyebabkan seringnya kesalahan dan keterlambatan dalam pembuatan laporan penjualan.

3. Saat Pembuatan kode barang yang belum ada kodenya, masih ditulis di atas kertas stiker kecil yang nantinya kode ini ditulis satu persatu sebanyak unit barang yang ada sehingga akan memakan waktu yang lama.

\subsection{Hipotesa}

Berdasarkan Perumusan Masalah diatas, Maka dapat dibentuk hipotesa sebagai berikut:

1. Pihak toko dapat menggunakan sistem komputer secara optimal sehingga komputer dapat digunakan sebagai pengolah data penjualan pada toko tersebut.

2. Pihak toko dapat menghasilkan faktur penjualan, laporan penjualan, laporan data barang, laporan suplier dan laporan pembelian dengan valid serta dapat menciptakan informasi yang dibutuhkan dengan akurat, efektif, aman dan cepat.

3. Dan juga pihak toko dapat membuat kode barang dalam bentuk Barcode ataupun QR Code dalam jumlah yang sesuai dengan unit barang yang ada secara sepat.

\subsection{Batasan Masalah}

Point Of Sale System pada Toko Rafadel, dibatasi pada satu toko serta untuk beberapa proses yaitu:

1. Data Barang

2. Data Satuan Barang

3. Data Jenis Barang

4. Transaksi Penjualan

5. Transaksi Pembelian

6. Laporan Stok Barang

7. Laporan Penjualan

8. Laporan Pembelian

9. Struk Penjualan

10. Cetak QR Code/Barcode Barang 
1.5 Maksud dan Tujuan

Maksud dan tujuan yang ingin di capai dalam penelitian ini adalah :

1. Memenuhi salah satu syarat untuk menyelesaikan studi jenjang Strata I jurusan Sistem Informasi di Universitas Putra Indonesia "YPTK" Padang.

2. Menerapkan teori-teori yang telah didapat selama dibangku perkuliahan dan membandingkannya dengan kenyataan di lingkungan masyarakat.

3. Menghasilkan perangkat lunak untuk mempermudah melakukan transaksi pada Toko Rafadel.

\subsection{Manfaat}

Adapun manfaat dari penelitian ini adalah:

1. Bagi peneliti, penelitian ini dapat di jadikan tantangan untuk menjadi pribadi yang lebih berkompeten di bidang sistem informasi.

2. Bagi Toko Rafadel, hasil penelitian ini dapat di implementasikan langsung dalam melakukan setiap transaksi.

3. Untuk Toko Lainnya, hasil penelitian ini dapat di jadikan acuan apabila ingin memiliki sistem informasi yang serupa untuk mendukung kinerjanya.

4. Hasil penelitian ini dapat di kembangkan dengan permasalahan yang lebih kompleks dan sesuai dengan kebutuhan di Toko lainnya.

\subsection{Ruang Lingkup Penelitian}

Agar permasalahan yang dibahas tidak menyimpang dari tujuan yang telah ditetapkan, dengan keterbatasan waktu dan pengetahuan, maka penulis membuat bahasan dalam penulisan Skripsi ini hanya pada bagian Point Of Sale System dari Toko Rafadel.

\subsection{Metodologi Penelitian}

Adapun metodologi penelitian yang di gunakan dalam penyusuna skripsi ini adalah:

1. Metode Observasi

Yaitu suatu metode penelitian dimana penulis secara lansung mendatangi atau mengamati obyek penelitian agar diperoleh informasi yang akurat dan dapat dipertanggung jawabkan
2. Metode Wawancara (Interview)

Yaitu metode pengumpulan data dengan mengadakan tanya jawab secara lansug terhadap pihak-pihak yang terkait yang menangani secara lansung data-data yang ada di Toko tersebut.

3. Metode Kearsipan (Arcive)

Yaitu metode penelitian yang di lakukan dengan menggunakan arsip yang diperoleh penulis dari Toko tersebut dalam bentuk dokumen, buku dan lembaran kertas lainnya.

4. Penelitian Pustaka (Library Research) Penelitian dengan menggunakan bukubuku yang berhubungan dengan pemecahan masalah dalam menunjang penyelesaian Skripsi ini.

5. Penelitian Labor (Laboratory Research)

Yaitu dengan melakukan penelitian laboratorium komputer dimana datadata yang diperoleh diproses dan dibuat programnya untuk menghasilkan suatu program aplikasi sesuai dengan permasalahan yang ada. Adapun Software dan Hardware yang dibutuhkan adalah:

1) Software

- Sistem Operasi Wicrosoft Windows 8.1

- Microsoft Office Word 2013

- Microsoft Office Visio 2013

- Microsoft Visual Studio 2013

- Microsoft SQL Server 2012

- SAP Crystal Report

2) Hardware

- Prosessor Intel Core i5-4210U

- HDD 500 GB

- RAM 4 GB

- Barcode Scaner

- Printer Biasa

- Printer Struk

\section{LANDASAN TEORI}

\subsection{Konsep Dasar Sistem}

Istilah sistem bukanlah hal yang asing bagi kebanyakan orang. Seringkali sistem mengacu pada komputer seperti IBM PC atau Macintosh, tetapi juga bisa ke arah yang lebih luas seperti sistem tata surya atau bahkan ke hal-hal yang lebih spesifik seperti sistem respirasi mamalia. 


\subsubsection{Pengertian Sistem}

Sistem adalah sekumpulan elemen yang saling terkait atau terpadu yang dimaksudkan untuk mencapai suatu tujuan. Sebagai gambaran, jika dalam sebuah sistem terdapat elemen yang tidak memberikan manfaat dalam mencapai tujuan yang sama, maka elemen tersebut dapat dipastikan bukan lah bagian dari sistem. Sebagai contoh, raket dan pemukul bola kasti (masing-masing sebagai elemen) tidak bisa membentuk sebuah sistem, karena tidak ada sistem permainan olahraga yang memadukan kedua peralatan tersebut.

\subsubsection{Elemen Sistem}

1. Tujuan

Setiap sistem memiliki tujuan (goal), entah hanya satu atau mungkin banyak. Tujuan inilah yang menjadi motivasi yang mengarahkan sistem. Tanpa tujuan, sistem menjadi tidak terarah dan tidak terkendali. Tentu saja, tujuan antara suatu sistem dengan sistem lain berbeda beda.

2. Masukan

Masukan sistem (input) adalah sistem segala sesuatu yang masuk kedalam sistem dan selanjutnya menjadi bahan untuk diproses. Masukan dapat berupa hal-hal berwujud (tampak secara fisik) maupun yang tidak tampak. Contoh masukan yang berwujud adalah bahan mentah sedangkan contoh yang tidak berwujud adalah informasi (misalnya permintaan jasa dari pelanggan).

3. Proses

Proses merupakan bagian yang melakukan perubahan atau transformasi dari masukan menjadi keluaran yang berguna, misalnya berupa informasi dan produk, tetapi juga bisa berupa hal-hal yang tidak berguna, misalnya saja sisa pembuangan atau limbah. Pada pabrik kimia, proses dapat berupa pemanasan bahan mentah. Pada rumah sakit, proses dapat berupa aktivitas pembedahan pasien.

4. Keluaran

Keluaran (output) merupakan hasil pemprosesan dari segala sesuatu masukan (input) dari suatu sistem baik itu keluarannya berupa fisik mupun keluarannya berupa nonfisik.
5. Umpan Balik

Umpan balik ini digunakan untuk mengendalikan baik masukan maupun proses. Tujuannya adalah untuk mengatur agar sistem berjalan sesuai dengan tujuan.

\subsubsection{Karakteristik Sistem}

Model umum sistem adalah input,proses, dan output. Hal ini merupakan konsep sebuah sistem yang sangat sederhana sebab sebuah sistem dapat mempunyai beberapa masukan dan keluaran. Selain itu, sebuah sistem mempunyai karakteristik atau sifat-sifat tertentu yang mecirikan bahwa hal tersebut bisa dikatakan sebagai suatu sistem. Adapun karakteristik yang dimaksud adalah sebagai berikut:

a. Komponen Sistem (Components)

Suatu sistem terdiri dari sejumlah komponen yang saling berinteraksi, artinya saling bekerjasama membentuk suatu kesatuan.

b. Batasan Sistem (Boundary)

Ruang lingkup sistem merupakan daerah yang membatasi antara sistem dengan sistem yang lain atau sistem dengan lingkungan luarnya.batasan sistem ini memungkinkan siatu sistem dipandang sebagai satu kesatuan yang tidak dapat dipisahkan.

c. Lingkungan Luar Sistem (Environtment)

Bentuk apapun yang ada diluar ruang lingkup atau batasan sistem yang mempengaruhi operasi sistem tersebut disebut lingkungan luar sistem.

d. Penghubung sistem (interface) Media yang menghubungkan sistem dengan sistem lain disebut penghubung sistem atau interface. Penghubung ini memungkinkan sumber-sumber daya mengalir dari satu subsistem ke subsistem yang lain.

e. Masukan Sistem (Input)

Energi yang dimasukkan kedalam sistem disebut masukan sistem, yang dapat berupa pemeliharaan (maintenance input) dan sinyal (Signal Input).

f. Keluaran Sistem (Output)

Hasil energi yang diolah dan diklasifikasikan menjadi keluaran yang berguna. 
g. Pengolahan Sistem (Proses)

Suatu sistem dapat mempunyai suatu proses yang akan mengubah masukan mnejadi keluaran, contohnya adalah sistem akuntansi.

h. Sasaran Sistem (Objective)

Suatu sistem memiliki tujuan dan sasaran yang pasti dan bersifat determinitic. Kalau suatu sistem tidak memiliki sasaran maka operasi sistem tidak ada gunanya.

\subsubsection{Daur Hidup Sistem}

Siklus hidup sistem (system life cycle) adalah proses evolusioner yang diikuti dalam menerapkan sistem atau subsistem informasi berbasis komputer. Siklus hidup sistem terdiri dari serangkaian tugas yang erat mengikuti langkah-langkah pendekatan sistem karena tugas-tugas tersebut mengikuti pola pola yang teratur dan dilakukan secara top down. Sisklus hidup sistem sering disebut sebagai pendekatan air terjun (waterfall approach) bagi pembangunan dan pengembangan sistem.

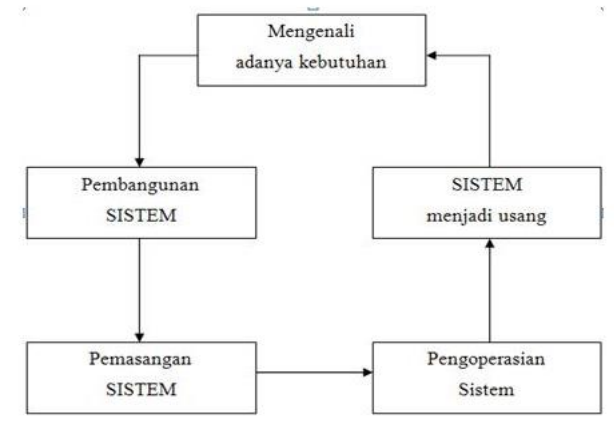

Gambar 2.1 Daur Hidup Sistem

Sumber : Tata Sutabri, 2012: 27

\subsubsection{Tahapan Pengembangan Sistem}

Dengan adamya tahapan pengembangan sistem, maka siklus hidup sistem dapat berjalan dengan baik. Tahapan pengembangan sistem secara umum terdiri atas enam tahapan. Dimulai dari survey, analisis, desain, pembuatan program, inplementasi, dan pemeliharaan. Jenis-jenis tahapan pengembangan sistem yang umum sudah dikenal yaitu dengan pendekatan model waterfall, iterasi dan spiral.

\section{Waterfall}

Bila menggunakan tahapan waterfall untuk pembuatan atau pengembangan sistem, setiap tahapan harus diselesaikan terlebih dahulu secara tuntas, sebelum melakukan ke tahapan berikutnya. Hal ini bertujuan untuk menghindari terjadinya pengulangan pada tahapan tersebut. Secara umum, pendekatan waterfall cendrung lama namun memiliki ketelitian pada setiap tahapan yang dilalui.

Berikut ini adalah gambaran tahap pengembangan sistem dengan model waterfall :

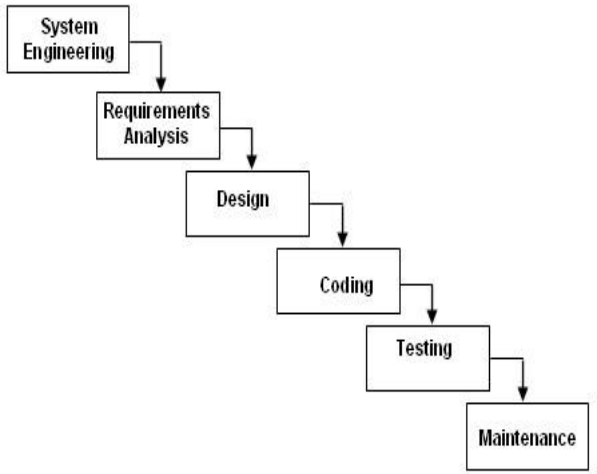

Gambar 2.2 Tahap pengembangan sistem model waterfall

Sumber : Tata Sutabri, 2012: 29

\section{Iterasi}

Tahapan Iterasi dikerjakan dengan menerapkan teknik iterasi (interation/pengulangan). Suatu tahapan proses dilaksanakan secara berulang ulang sampai mendapatkan hasil yang diinginkan.

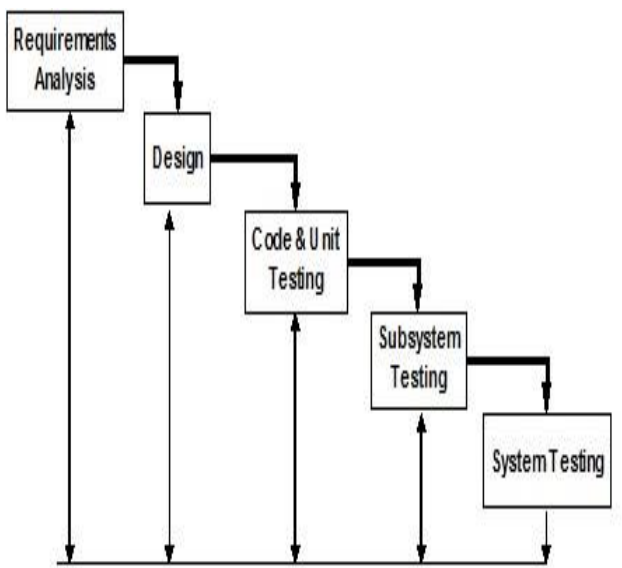

Gambar 2.3 Tahap pengembangan sistem model iterasi

Sumber : I Gusti Ngurah Suryantara, 2014: 8 


\section{Spiral}

Tahapan spiral penerapannya hampir sama dengan penerapan iterasi. Yaitu suatu tahapan proses dilaksanakan secara berulang ulang sampai mendapatkan hasil yang diinginkan.

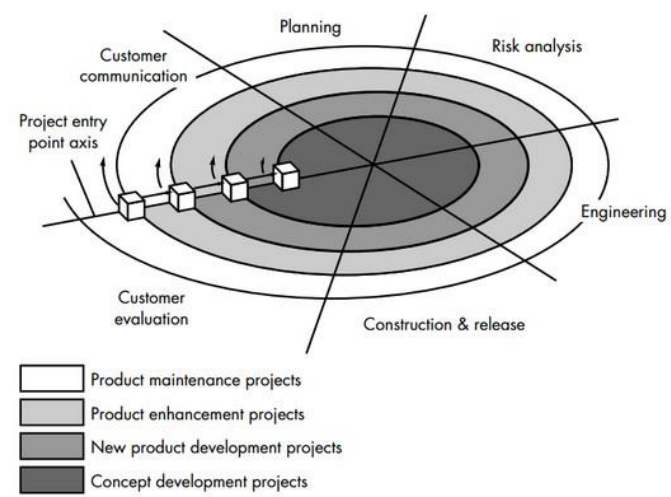

Gambar 2.4 Tahap pengembangan sistem model spiral

Sumber : I Gusti Ngurah Suryantara, 2014: 8

\subsection{Konsep Dasar Informasi}

Informasi merupakan salah satu sumber daya penting dalam manajemen modern. Banyak keputusan strategis yang bergantung kepada informasi, dan informasi merupakan sumber daya vital bagi kelangsungan organisasi bisnis.

\subsubsection{Pengertian Informasi}

McFadden, dkk.(1999) mendefenisikan informasi sebagai data yang telah diproses sedemikian rupa sehingga meningkatkan pengetahuan seseorang yang menggunakan data tersebut. Shannon dan Weaver, dua orang insinyur listrik, melakukan pendekatan secara matematis untuk mendefenisikan informasi (Kroenke, 1992). Menurut mereka, informasi adalah "jumlah ketidakpastian yang dikurangi ketika sebuah pesan diterima". Artinya dengan adanya informasi, tingkat kepastian menjadi meningkat. Menurut davis (1999), informasi adalah data yang telah di olah menjadi sebuah bentuk yang berarti bagi penerimanya dan bermanfaat dalam pengambilan keputusan saat ini atau saat mendatang.

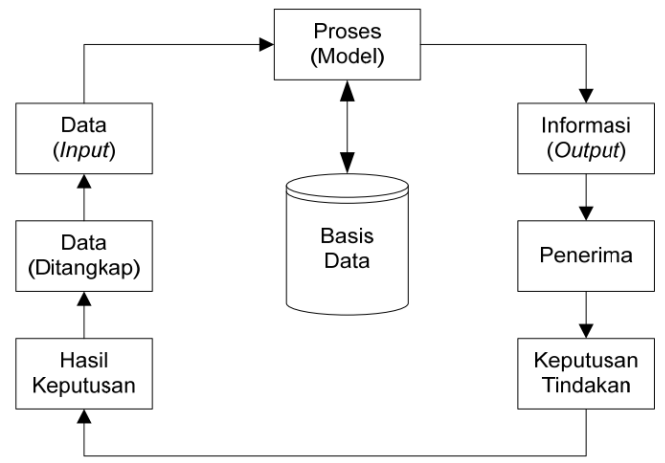

Gambar 2.5 Siklus Informasi

Sumber Abdul Kadir, 2014: 45

\subsubsection{Kualitas Informasi}

Istilah kualitas informasi (quality of information) terkadang juga dipakai untuk menyatakan informasi yang baik. Kualitas informasi seringkali diukur berdasarkan akurasi,ketepatan waktu, dan relevan.

Kualitas informasi dapat dianalogikan sebagai pilar-pilar dalam bangunan (Burch dan Grudnitski, 1989) dan menentukan baik tidaknya pengambilan keputusan.

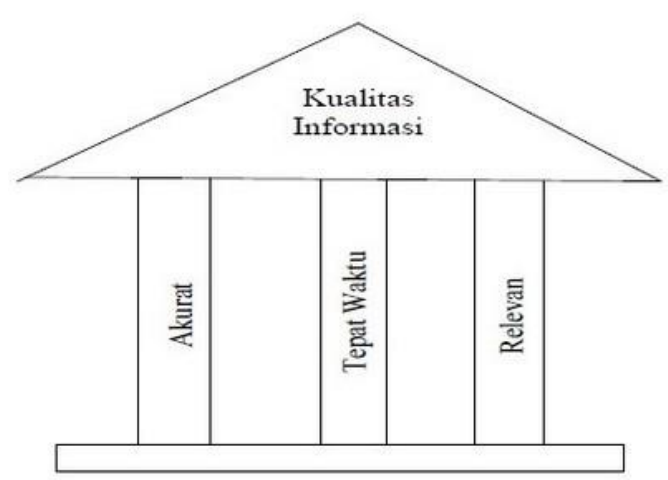

Gambar 2.6 Kualitas Informasi

Sumber Abdul Kadir, 2014: 56

1. Akurat (Accurate)

Informasi harus bebas dari kesalahankesalahan, tidak bias dan menyesatkan. Informasi harus akurat karena dari sumber informasi sampai ke penerima informasi kemungkinan banyak terjadi gangguan yang dapat merubah atau merusak informasi tersebut.

2. Tepat Pada Waktunya (Timeliness)

Informasi yang datang kepada penerimanya tidak boleh terlambat. Informasi yang sudah usang tidak akan mempunyai nilai lagi, karena informasi merupakan landasan didalam 
pengambilan keputusan. Bila pengambilan keputusan terlambat maka berakibat fatal untuk organisasi.

3. Relevan (Relevance)

Relevan berarti informasi tersebut mempunyai manfaat untuk pemakainya. Relevansi informasi untuk tiap-tiap orang satu dengan lainnya berbeda.

\subsection{Konsep Dasar Sistem Informasi \\ 2.3.1 Pengertian Sistem Informasi}

Sesungguhnya, yang dimaksud dengan

sistem informasi tidak harus melibatktan komputer. Sistem informasi yang menggunakan komputer biasa disebut sistem informasi berbasis komputer (Computer based informastion system atau CBIS). Dalam praktik, istilah sistem informasi lebih sering dipakai tanpa embel-embel berbasis komputer walaupun dalam kenyataannya komputer merupakan bagian yang penting.

Ada beragam defenisi tentang sistem informasi dari berbagai sumber diantaranya yaitu :

1. Alter (1992)

Sistem informasi adalah kombinasi antara prosedur kerja, informasi, orang, dan teknologi informasi yang diorganisasikan untuk mencapai tujuan dalam sebuah organisasi.

2. Bodhar dan Hopwood (1993)

Sistem informasi adalah kumpulan perangkat keras dan perangkat lunak yang di rancang untuk mentransformasikan data ke dalam bentuk informasi yang berguna.

3. Gelinas, Oram Dan Wiggins (1990) Sistem informasi adalah suatu sistem buatan manusia yang secara umum terdiri atas sekumpulan komponen berbasis komputer dan manual dibuat untuk menghimpun, menyimpan dan mengolah data serta menyediakan informasi keluaran kepada para pemakai.

4. Hall (2001)

Sistem informasi adalah sebuah rangkaian prosedur formal dimana data dikelompokkan, diproses menjadi informasi dan didistribusikan kepada pemakai.

5. Turban, McLean, Dan Wetherbe (1999)
Sebuah sistem informasi mengumpulkan, memproses, menyimpan, menganalisis, dan menyebarkan informasi untuk tujuan yang spesifik.

6. Wilkinson (1992)

Sistem informasi adalah kerangka kerja yang mengoordinasikan sumber daya (manusia, komputer) untuk mengubah masukan (input) menjadi keluaran (informasi), guna mencapai sasaransasaran perusahaan.

\subsubsection{Komponen Sistem Infomasi}

Sistem informasi mengandung komponen-komponen seperti berikut :

\section{Perangkat Keras (hardware)}

Yang mencakup piranti piranti fisik seperti komputer, printer, keyboard dan monitor

2. Perangkat Lunak (software)

Sekumpulan instruksi yang memungkinkan perangkat keran memproses suatu data.

\section{Prosedur}

Yaitu sekumpulan aturan yang dapakai untuk mewujudkan pemrosesan data dan pembangkitan keluaran yang dikehendaki.

\section{Orang}

Yakni semua pihak yang bertanggung jawab dalam pengembangan sistem informasi, pemprosesan,dan penggunaan keluaran informasi.

\section{Basis Data (database)}

Yaitu kumpulan tabel, hubungan, dan lain-lain yang berkaitan dengan penyimpanan data.

6. Jaringan komputer dan komunikasi data

Yaitu sistem penghubung yang memungkinkan (sumber) dipakai secara bersama atau diakses oleh sejumlah pemakai. 


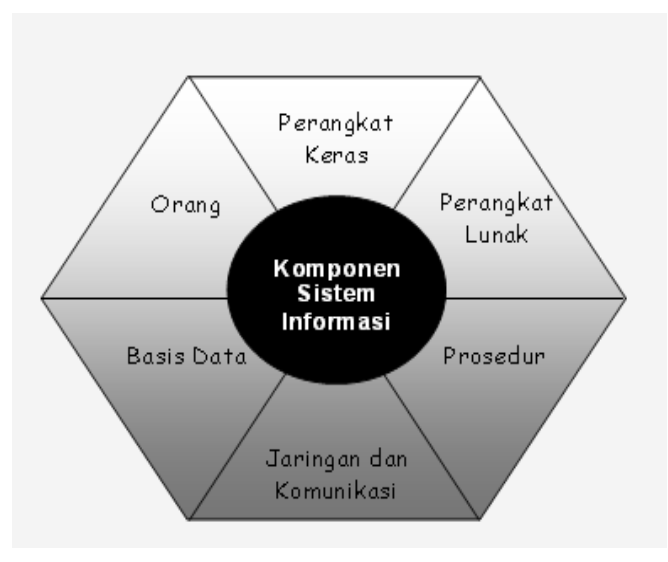

Gambar 2.7 Komponen Sistem Informasi

Sumber Abdul Kadir, 2014: 71

\subsubsection{Manfaat Sistem Informasi}

Sistem informasi memiliki banyak manfaat, diantaranya :

1. Menghemat tenaga kerja

2. Peningkatan efisiensi

3. Mempercepat proses

4. Perbaikan dokumentasi

5. Pencapaian standar

6. Perbaikan keputusan

\subsection{Pengembangan Sistem}

Pengembang sistem dapat berarti menyusun sistem yang baru untuk menggantikan sistem yang lama secara keseluruhan atau memperbaiki sistem yang telah ada. Sistem yang lama perlu diperbaiki karena adanya permasalahan-permasalahan yang timbul di sistem yang lama.

Siklus hidup Pengembangan sistem (System Development Life Cycle) atau SDLC merupakan suatu bentuk yang digunakan untuk menggambarkan tahapan dan langkah-langkah didalam tahapan tersebut dalam proses pengembangannya. Tahapan tersebut terdiri dari:

1. Kebijakan dan Perencanaan Sistem Kebijakan sistem (system policy) merupakan landasan dan dukungan dari manajemen puncak untuk membuat perencanaan sistem. Perencanaan sistem (system planning) merupakan pedoman untuk melakukan pengembangan sistem.

\section{Analisa Sistem}

Analisa sistem merupakan tahapan menganalisis sistem untuk menemukan kelemahan-kelemahannya sehingga dapat diusulkan perbaikannya.

\section{Desain (perancangan) sistem secara} umum

Desain sistem secara umum merupakan persiapan dari desain terinci yang mengindentifikasikan komponenkomponen sistem informasi yang akan didesain secara rinci.

4. Desain (perancangan) sistem terinci Desain sistem terinci dimaksudkan untuk pemrograman komputer dan ahli teknik lainnya yang akan mengimplementasikan sistem.

\section{Seleksi Sistem}

Seleksi sistem merupakan tahap untuk memilih perangkat keras dan perangkat lunak untuk sistem informasi.

6. Implementasi

Implementasi sistem yaitu tahapan menerapkan sistem supaya sistem siap dioperasikan.

\section{Perawatan Sistem}

Perawatan sistem merupakan tahapan setelah pengembang sistem selesai dilakukan atau sistem telah dioperasikan.

Tahapan dalam Siklus Pengembang Sistem atau System Development Life Cycle ( SDLC ) sebagai berikut:

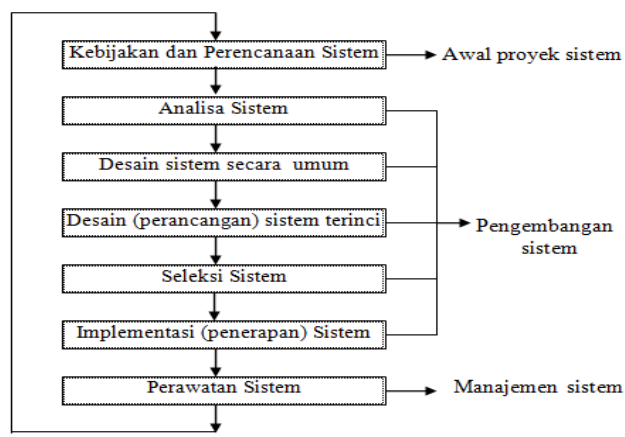

\section{Gambar 2.8 Siklus Hidup Pengembangan Sistem}

Sumber Abdul Kadir, 2014: 345

\subsection{Analisis Sistem}

Tahapan Analisis sistem dimulai karena adanya permintaan terhadap sistem baru. Permintaan dapat datang dari seorang manager diluar departemen sistem informasi atau dari pihak eksekutif dan melihat adanya masalah atau menemukan adanya peluang baru. Namun adakalanya inisiatif pengembangan sistem baru berasal dari bagian yang bertanggung jawab terhadap pengembangan sistem informasi, yang bermaksud mengembangkan sistem yang sudah ada atau mengatasi masalah-masalah yang belum tertangani. 


\subsubsection{Pengertian Analisis Sistem}

1. Menurut Yogiyanto (1995)

analisis sistem adalah penguraian dari suatu sistem informasi yang utuh kedalam bagianbagian komponennya dengan maksud untuk mengidentifikasikan dan mengevaluasi permasalahan, kesempatan, hambatan yang terjadi dan kebutuhan yang diharapkan sehingga dapat diusulkan perbaikan.

2. Menurut Kristanto (2003)

analisis sistem adalah suatu proses mengumpulkan dan menginterpretasikan kenyataankenyataan yang ada, mendiagnosa persoalan dan menggunakan keduanya untuk memperbaiki sistem.

3. Menurut Yogiyanto (1995)

analis sistem (analis informasi) adalah orang yang menganalis system (mempelajari masalahmasalahan yang timbul dan menentukan kebutuhan pemakai sistem) untuk mengidentifikasikan pemecahan permasalahan tersebut.

4. Menurut Kristanto (2003)

analis sistem adalah orang yang mempunyai kemampuan untuk menganalisis sebuah sistem, memilih alternatifpemecahan masalah dan menyelesaikan masalah tersebut dengan menggunakan komputer.

\subsubsection{Peranan Analisis Sistem}

Analis sistem secara sistematis menilai bagaimana fungsi bisnis dengan cara mengamati proses input dan pengolahan data serta proses output informasi untuk membantu peningkatan proses organisasional. Dengan demikian, analis sistem mempunyai tiga peranan penting, yaitu :

1. Sebagai konsultan

2. Sebagai ahli pendukung

3. Sebagai agen perubahan

\subsubsection{Tugas Analisis Sistem}

Adapun tugas-tugas yang dilakukan oleh seorang analis sistem adalah :

1. mengumpulkan dan menganalisis semua dokumen, file, formulir yang digunakan pada sistem yang telah berjalan.

2. menyusun laporan dari sistem yang telah berjalan dan mengevaluasi kekurangankekurangan pada sistem tersebut dan melaporankan semua kekurangan tersebut kepada pemakai sistem.

3. merancang perbaikan pada sistem tersebut dan menyusun sistem baru.

4. menganalisis dan menyusun perkiraan biaya yang diperlukan untuk sistem yang baru dan memberikan argumen tentang keuntungan yang dapat diperoleh dari pemakian sistem yang baru tersebut.

5. mengawasi semua kegiatan terutama yang berkaitan dengan sistem yang baru tersebut.

\section{ANALISA DAN PERANCANGAN SISTEM}

\subsection{Analisa Sistem Yang Sedang Berjalan}

Tahapan analisis sistem di mulai karena adanya permintaan terhadap sistem yang baru. Permintaan dapat datang karena adanya permasalahan pada sistem yang yang sedang berjalan dan menemukan adanya peluang yang baru. Dengan adanya analisa sistem di harapkan dapat menentukan hal- hal detail mengenai yang akan di kerjakan oleh sistem yang diusulkan.

Analisa sistem yang sedang berjalan pada prinsipnya adalah mempelajari sistem yang sedang ada dengan melakukan pengidentifikasian dan mengevaluasi permasalahan- permasalahan, kesempatankesempatan, hambatan- hambatan dan kebutuhan- kebutuhan yang diharapkan dan pengamatan terhadap unit kerja yang terlibat dalam proses pengolahan data penjualan.

Agar analisa sistem dapat berjalan dengan baik perlu dilakukan kegiatan seperti studi kelayakan dan analisa kebutuhan. Studi kelayakan digunakan untuk memastikan bahwa solusi yang diusulkan tersebut benar- benar dapat dicapai dengan sumber daya dan dengan memperhatikan kendala yang terdapat pada perusahaan dan terhadap lingkungan sekelilingnya. Sedangkan analisa kebutuhan digunakan untuk dapat menghasilkan spesifikasi kebutuhan yaitu spesifikasi yang rinci tentang hal- hal yang akan dilakukan sistem ketika diimplementasikan. 


\subsubsection{Sistem Yang Sedang Berjalan}

Sebelum mengembangkan sistem yang baru maka terlebih dahulu kita harus paham terhadap sistem yang telah ada, hal ini dilakukan untuk mengetahui kekurangankekurangan yang terjadi dan masalah-masalah yang ditemukan pada sistem tersebut. Penelitian ini memfokuskan untuk mengetahui terhadap masalah yang berhubungan dengan pengolahan data penjualan (Point Of Sale).

Pada Toko Rafadel dalam melakukan pengolahan data penjualan masih dilakukan secara manual dan belum adanya database penjualan sehingga informasi yang dihasilkan sering terjadi kesalahan dan keterlambatan. Dalam penyusunan sistem informasi data penjualan yang nantinya menghasilkan faktur penjualan, laporan data barang, laporan data suplier serta laporan data penjualan sangat memakan waktu yang lama, yang mana pemilik toko akan mengumpulkan semua bukti- bukti transaksi yang akan diolah secara manual. Kegiatan- kegiatan seperti inilah yang di lakukan secara berulang-ulang sehingga membutuhkan waktu yang lama dan memungkinkan terjadinya kesalahan- kesalahan

Untuk lebih jelasnya bagaimana informasi berjalan pada toko tersebut, kita dapat menggunakan Aliran Sistem Informasi (ASI). Dengan adanya gambar ASI akan lebih mudah memahami dengan jelas informasi berpindah antara bagian dengan bagian lain.

Adapun aliran sistem informasi yang terdapat pada Toko Rafadel pada saat ini dapat kita lihat pada gambar berikut :

\section{Aliran Sistem Informasi (ASI) Lama}

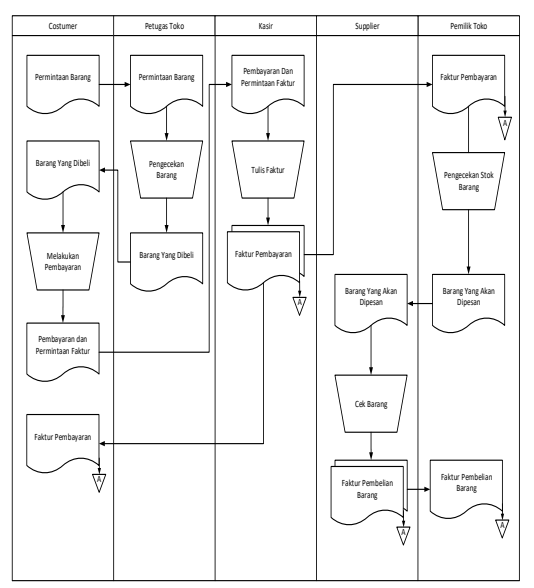

Gambar 3.1 Aliran Sistem Informasi Lama (ASI Lama)

Berdasarkan pengamatan yang dilakukan pada Toko Rafadel, Jl. Andalas No.80 Kota Padang, maka dapat dijelaskan bagaimana system ini berjalan. Berikut adalah data penjualan, dan faktur pembelian dari sistem lama tersebut :

\section{Data Penjualan Barang}

Semua transaksi penjualan pada toko rafadel di catat ke dalam sebuah buku yang telah disediakan oleh pemilik toko. berikut adalah gambaran data transaksi penjualan dari sistem yang lama.

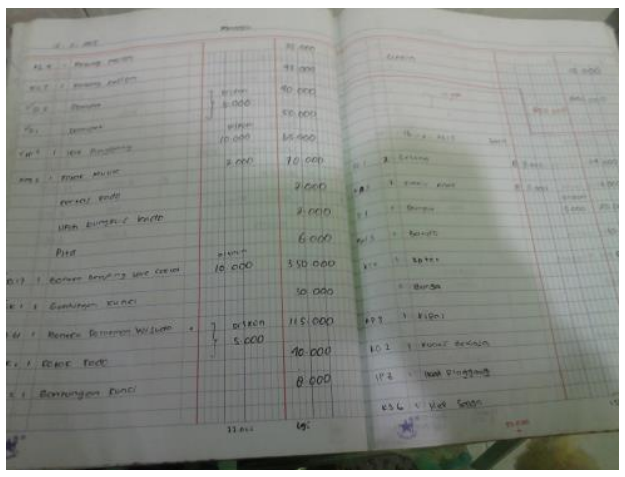

Gambar 3.2 Data penjualan dari sistem lama

\section{Faktur Pembelian Barang}

Pemilik toko mengumpulkan semua faktur pembelian barang ke supplier sebagai pedoman dalam penyesuaian harga jual yang akan di jual lagi kepada costomer dan juga sebagai pedoman penghitungan laporan pembelian barang. Berikut ini adalah gambaran dari faktur pembelian barang kepada supplier.

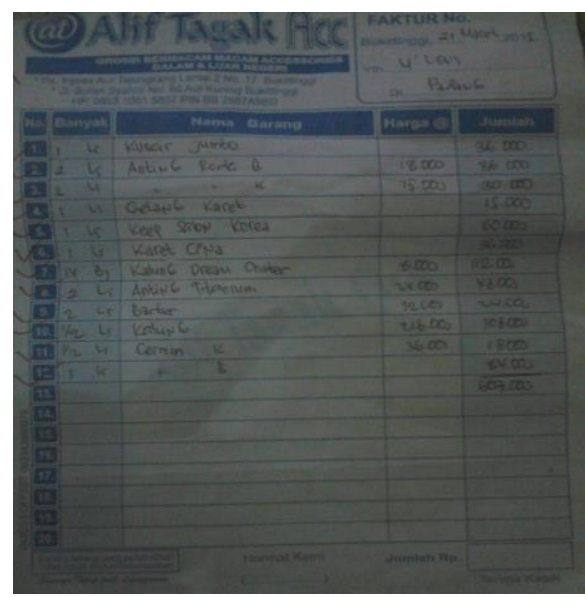

Gambar 3.3 Faktur pembelian dari sistem lama 


\subsubsection{Kelemahan Sistem Yang Sedang Berjalan}

Pengolahan data penjualan pada Toko Rafadel pada saat sekarang ini terdapat beberapa kelemahan. Kelemahan-kelemahan tersebut adalah:

1. Pengolahan data penjualan dan pembelian barang yang masih manual menyebabkan pengolahan data dilakukan sangat lambat dan seringnya kesalahan dalam pembuatan laporan.

2. Pengolahan data penjualan yang belum memiliki database sehingga sering kesulitan mencari data yang dibutuhkan.

\subsection{Desain Sistem}

Disain sistem hanya dapat dilakukan setelah dilakukan penganalisaan terhadap sistem yang lama. Disain sistem dilakukan untuk menutupi kelemahan yang terhadap disain sistem yang sedang berjalan. Sistem yang baru ini di rancang untuk melakukan perobahan pengolahan data penjualan yang sebelumnya masih manual serta belum adanya database menjadi sistem yang diolah secara komputerisasi dan sudah memiliki database dengan menggunakan bahasa pemograman Visual Basic.Net 2013 dan penyimpanan data menggunakan database Microsoft SQL Server 2012.

\subsubsection{Disain Sistem Secara Global}

Pada disain global ini akan membahas secara garis besar mengenai sistem informasi yang akan di rancang, Adapun aliran sistem informasi yang baru dapat di lihat sebagai berikut :

\section{Aliran Sistem Informasi (ASI) Baru}

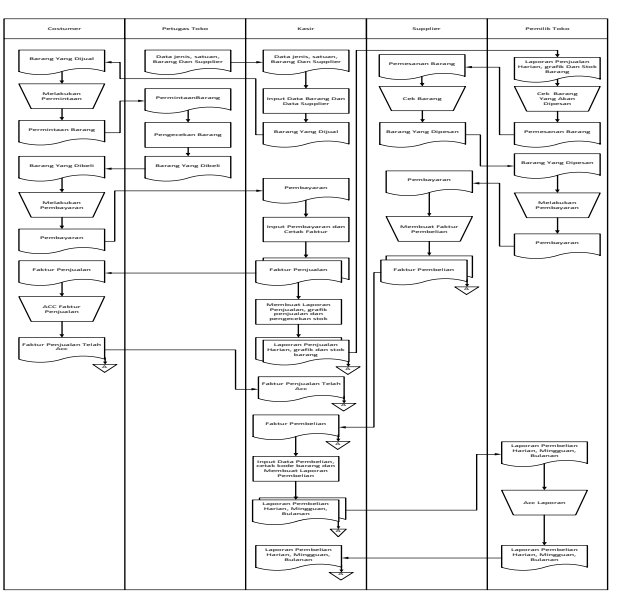

Gambar 3.4 Aliran Sistem Informasi Baru (ASI Baru)

\subsubsection{Contex Diagram (CD)}

Contex Diagram pada perancangan Point Of Sale Sistem di Toko Rafadel dijelaskan sebagai berikut:

1. Petugas toko mendata barang yang terdapat di toko. Lalu petugas toko mendapatkan informasi stock barang. Informasi stok barang juga diterima oleh kasir/ operator.

2. Supplier menyerahkan data supplier ke petugas toko, lalu petugas toko memasukkan data supplier ke dalam system.

3. Pemilik toko menyerahkan data order barang yang dibutuhkan oleh toko. Lalu data tersebut diterima oleh supplier. Kemudian supplier mengirim data barang order tersebut. Data barang order tersebut diterima oleh bagian toko.

4. Customer menyerahkan barang yang dibeli ke kasir/operator. Lalu kasir/ operator memasukkan data tersebut kedalam sistem. Kemudian customer menerima struk belanja.

5. Pemilik Toko menerima laporan dari semua transaksi yang dilakukan.

Rancangan program dalam bentuk Contex Diagram Point Of Sale Sistem pada Toko Rafadel dapat dilihat pada gambar 3.5

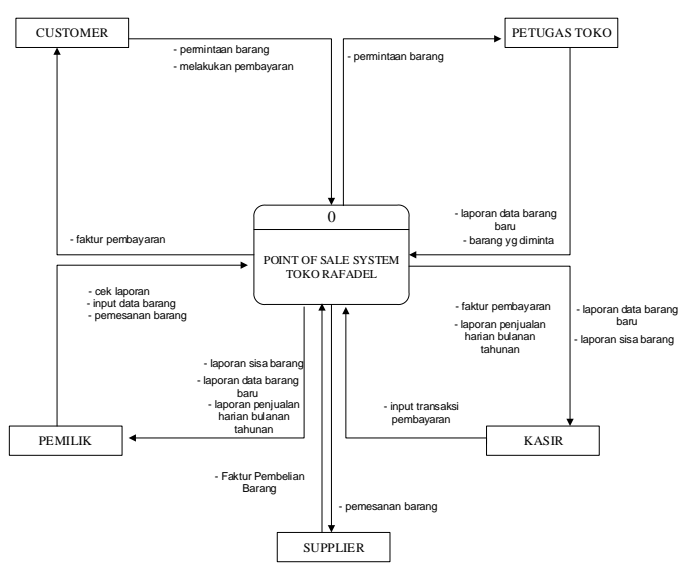

Gambar 3.5 Contex Diagram

\subsubsection{Data Flow Diagram (DFD)}

DFD adalah bagian yang menggambarkan keseluruhan kerja sistem secara garis besar. DFD menggambarkan penyimpanan data dan proses yang mentransformasikan data dan menunjukkan 
hubungan antara data pada sistem dan proses pada sistem.

DFD level 0 dari Sistem Penjualan di Toko Rafadel dijelaskan sebagai berikut:

1. Petugas toko mendata barang lalu akan disimpan pada data store barang. Informasi stock barang akan diterima oleh petugas toko dan juga kasir / operator.

2. Supplier memberikan data supplier pada proses pendataan supplier dan disimpan pada data store supplier.

3. Pada proses pembelian, petugas toko akan menyerahkan data order barang yang dibutuhkan oleh toko kepada supplier. Lalu supplier mengirim data barang order tersebut dan diterima oleh petugas toko. Data pembelian disimpan pada data store pembelian. Data barang yang kurang sesuai atau rusak akan mengalami retur pembelian ke supplier.

4. Pada proses penjualan, customer akan memberikan data barang yang dibeli pada proses penjualan. Kemudian data barang yang dibeli akan dibaca olah kasir serta kasir akan memasukkan data barang yang dibeli tersebut. Pada proses penjualan, bagian toko akan menerima informasi stock barang,. Karena pada proses ini penjualan otomatis akan terbaca di data store barang. Kemudian data penjualan akan disimpan pada data store penjualan. Terakhir customer akan menerima struk belanja.

5. Data penjualan, data pembelian, data supplier, dan data barang yang terjadi pada proses-proses tersebut akan diolah pada proses pelaporan dan menghasilkan laporan yang akan diterima oleh manajemen. Rancangan program dalam bentuk DFD level 0 dari Sistem Informasi Penjualan di Toko Radadel dapat dilihat pada gambar Berikut :

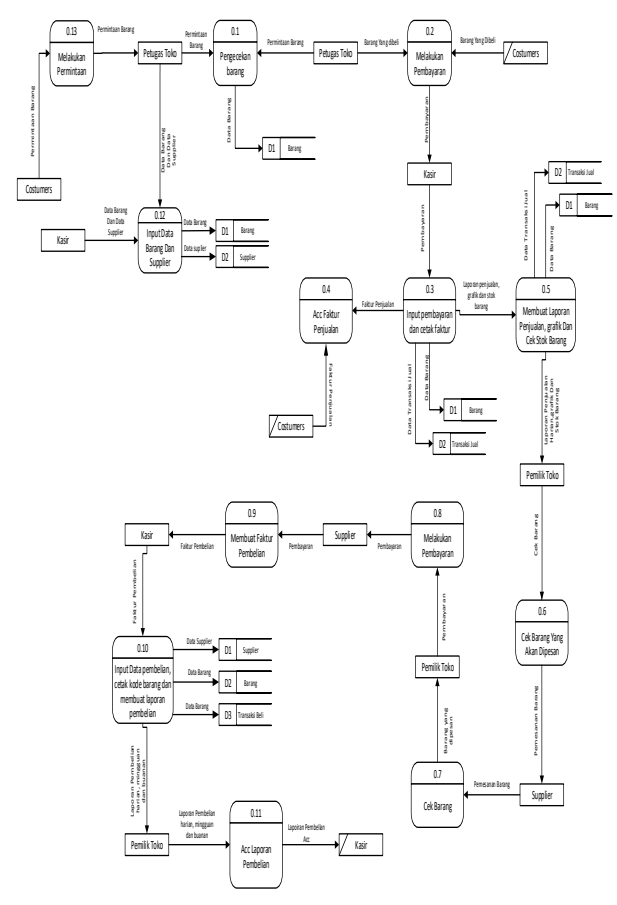

Gambar 3.6 Data Flow Diagram

3.2.4 Entity Relationship Diagram (ERD) ERD adalah bagan yang menunjukan hubungan antar entity yang ada dalam sistem. Adapun gambaran ERD yang digunakan dapat di lihat sebagai berikut :

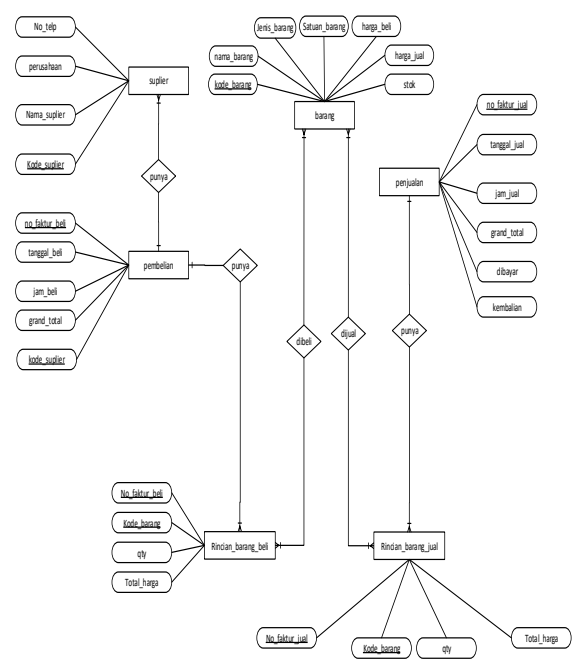

Gambar 3.7 Entity Relationship Diagram 


\section{IMPLEMENTASI SISTEM}

\subsection{Implementasi Sistem}

Tahap implementasi sistem merupakan salah satu tahap dalam daur ulang hidup pengembangan sistem, dimana tahap ini merupakan tahap meletakan sistem informasi supaya siap untuk dipakai. Dalam tahap ini berlangsung beberapa aktifitas secara berurutan yakni mulai dari menerapkan rencana implementasi, melakukan kegiatan implementasi, dan tindak lanjut implementasi.

Untuk menjalankan sistem atau program yang telah dibuat akan dijelaskan sebagai berikut:

\subsection{Implementasi Program}

Pada bab ini akan di jelaskan bagaimana Aplikasi Point Of Sale System pada Toko Rafadel terdiri dari form-form sebagai berikut :

\subsubsection{Tampilan Form Menu Utama}

Setelah proses loading selesai maka masuk ke menu home. Jika username adalah kasir maka hanya dapat mengakses transaksi penjualan dan pembelian saja. Tetapi jika username pemilik toko maka dapat membuka transaksi pembelian, penjualan, barang, supplier, dan laporan.

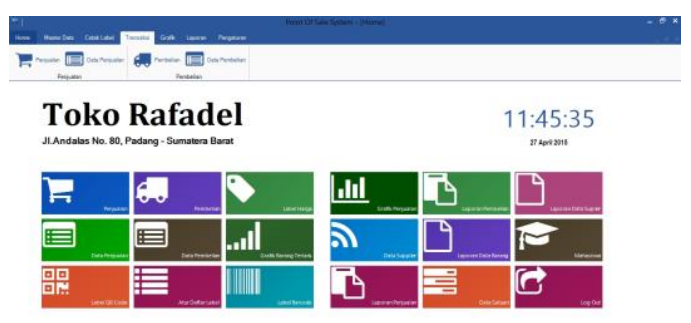

Gambar 4.1 Form Menu Utama

\subsubsection{Tampilan Form Input Barang Baru}

Form input barang baru merupakan form yang digunakan untuk menginputkan data barang yang baru masuk.

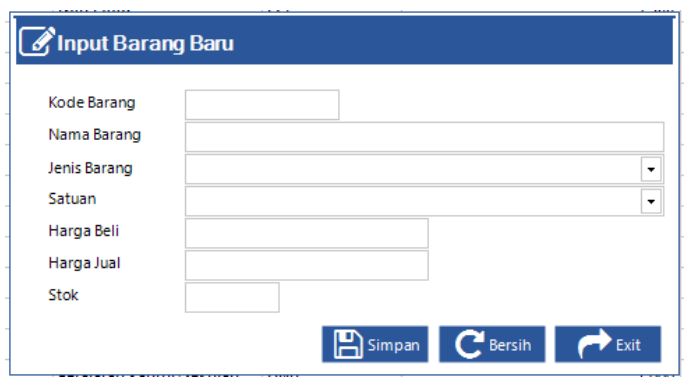

Gambar 4.2 Form Input Barang Baru

\subsubsection{Tampilan Form Data Barang}

Form data barang merupakan form yang digunakan untuk pengecekan stok barang yang tersedia maupun maupun yang telah habis, pada form ini terdapat fitur edit, hapus dan pencarian data barang.

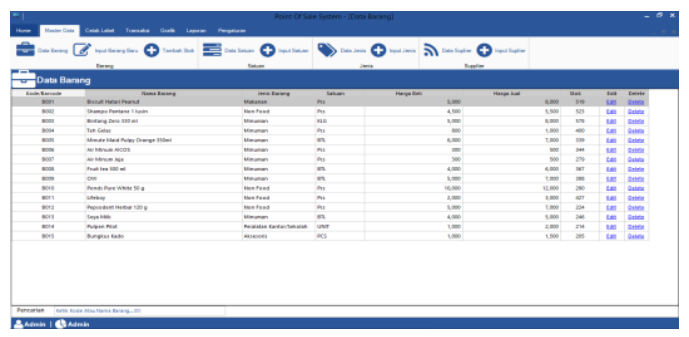

Gambar 4.3 Form Data Barang

\subsubsection{Tampilan Form Tambah Stok Barang}

Form tambah tok barang merupakan form yang di gunakan untuk menambahkan stok barang untuk barang yang telah terdaftar di data barang.

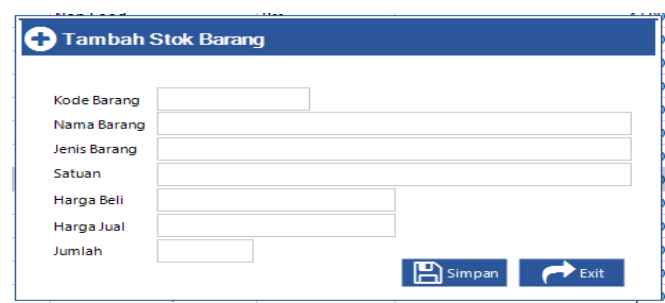

Gambar 4.4 Form Tambah Stok Barang

\subsubsection{Tampilan Form Edit Data Barang}

Form edit data barang merupakan form yang digunakan untuk mengedit/mengubah data barang yang salah input.

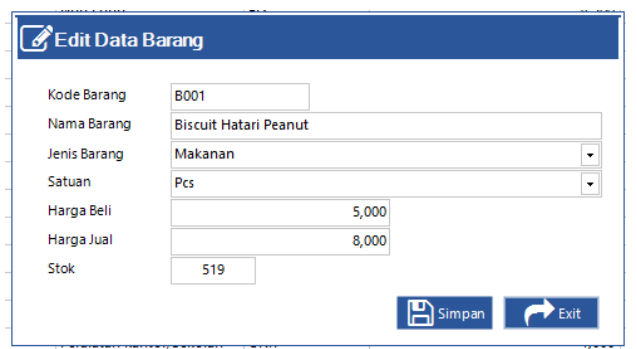

Gambar 4.5 Form Edit Data Barang

\subsubsection{Tampilan Input Data Suplier}

Form input data suplier merupakan form yang digunakan untuk menginputkan data suplier 


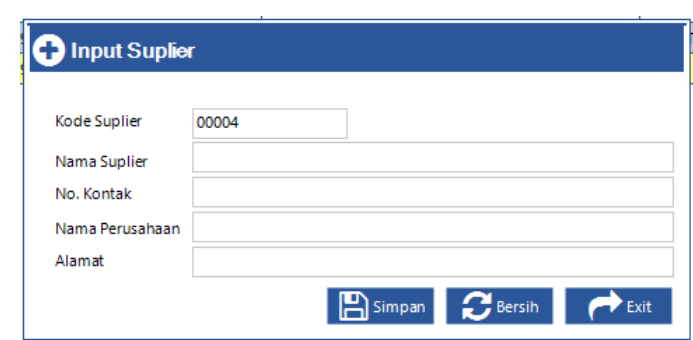

Gambar 4.6 Form Iput Suplier

\subsubsection{Tampilan Form Data Suplier}

Form data suplier merupakan form yang digunakan untuk mengecek data suplier yang telah diinputkan.

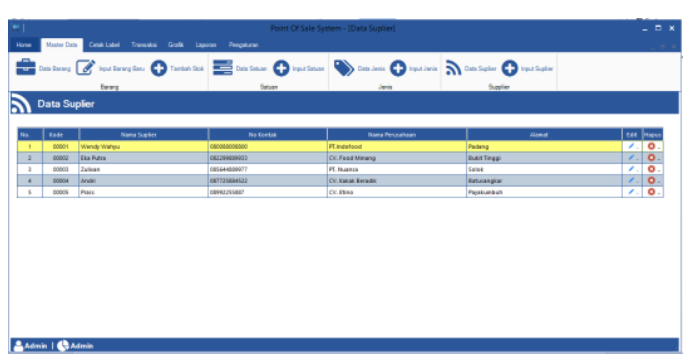

Gambar 4.7 Form Data Supplier

\subsubsection{Tampilan Form Edit Data Suplier}

Form edit data suplier merupakan form yang di gunakan untuk merubah data suplier yang salah input atau ada perubahan data.

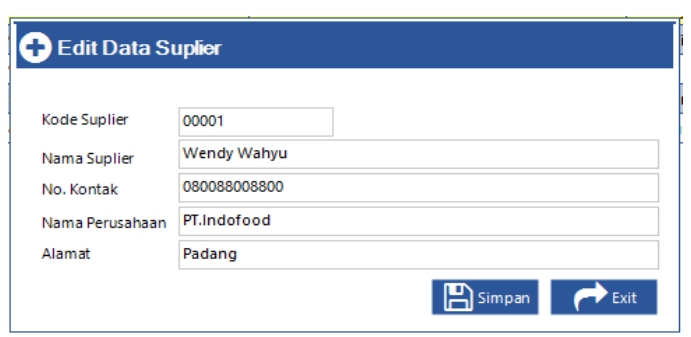

Gambar 4.8 Form Edit Data Suplier

\subsubsection{Tampilan Form Atur Data Label}

Form atur data label merupakan form yang digunakan untuk mengatur kode kode barang yang akan di cetak kodenya baik dalam bentuk barcode maupun QR code.

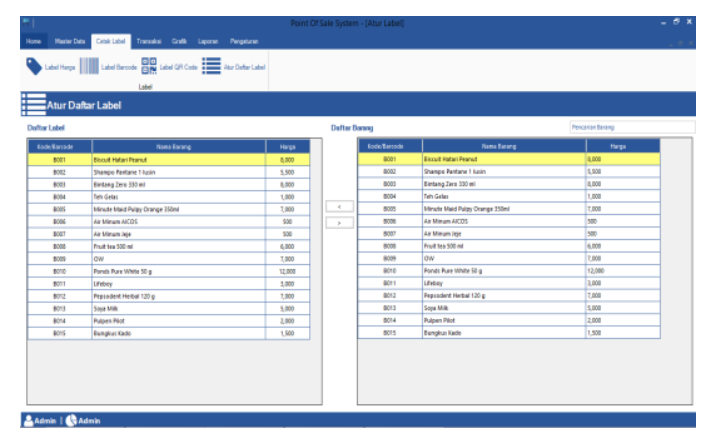

Gambar 4.9 Form Atur Data Label

\subsubsection{Tampilan Cetak QR Code Barang}

Cetak QR Code barang merupakan label kode barang untuk barang yang belum tersedia kodenya, yang nanti label ini akan mempermudah kasir dalam menginputkan barang pada transaksi penjualan barang.
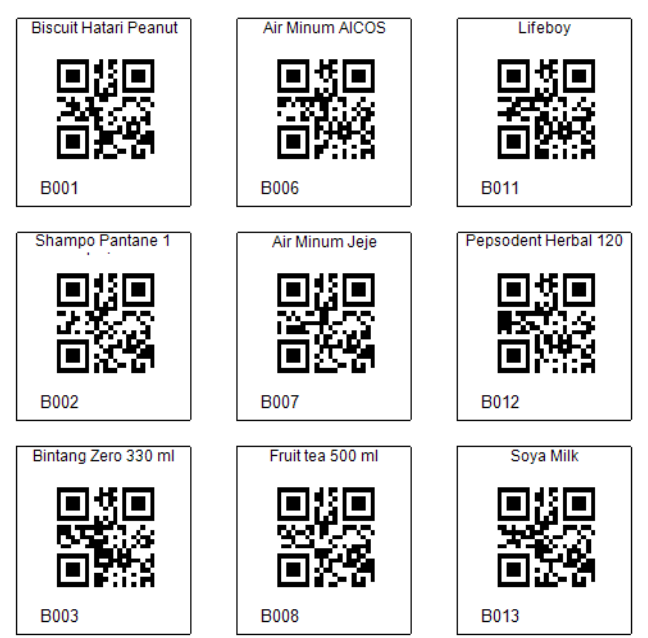

Gambar 4.10 QR Code Barang

\subsubsection{Tampilan Cetak Barcode Barang}

Cetak Barcode barang merupakan label kode barang untuk barang yang belum tersedia kodenya, yang nanti label ini akan mempermudah kasir dalam menginputkan barang pada transaksi penjualan barang. 

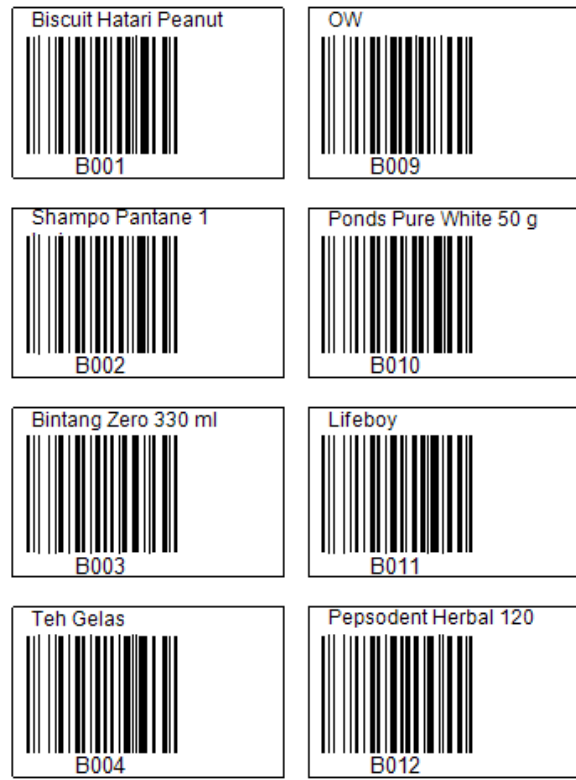

Gambar 4.11 Barode Barang

\subsubsection{Tampilan Form Transaksi Penjualan}

Form Transaksi Penjualan merupakan form yang digunakan untuk menginputkan barang barang yang di beli oleh customers.

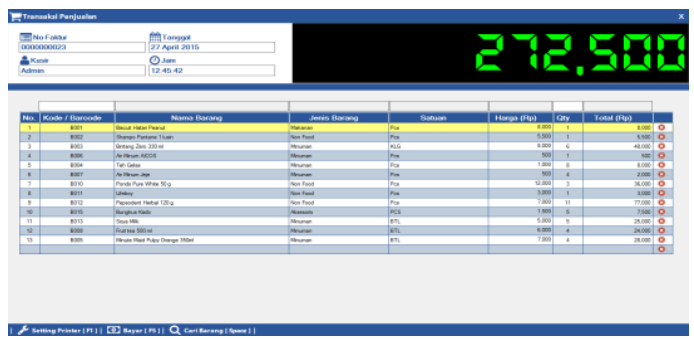

Gambar 4.12 Form Penjualan Barang

\subsubsection{Tampilan Form Pembayaran}

Form pembayaran merupakan form yang digunakan untuk menginputkan pembayaran yang dilakukan oleh customers.

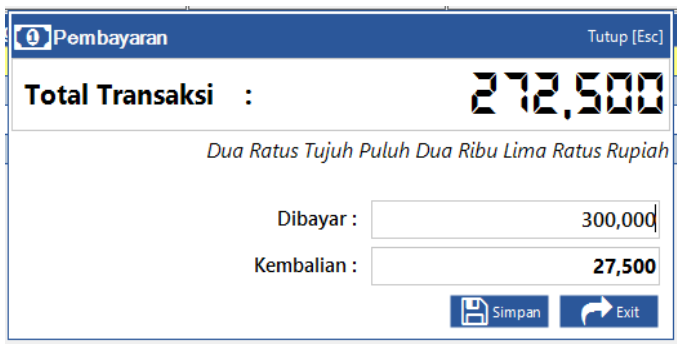

Gambar 4.13 Form Pembayaran

\subsubsection{Tampilan Faktur Pembelian}

Faktur pembelian merupakan bukti transaksi yang akan diberikan kepada customer setelah melakukan transaksi pembelian.

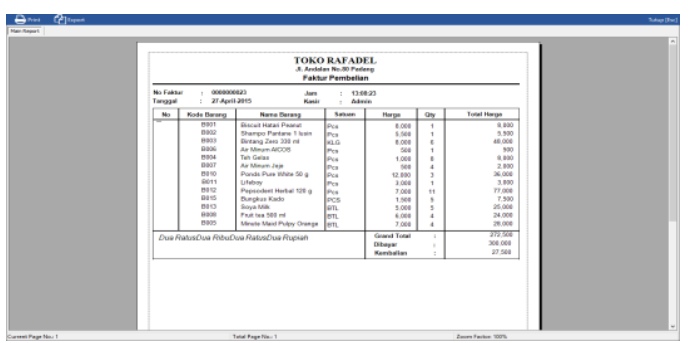

Gambar 4.14 Faktur Pembelian

\subsubsection{Tampilan Form Transaksi Pembelian}

Form Transaksi Pembelian merupakan form yang digunakan untuk mengimputkan data barang yang telah di beli kepada suplier.

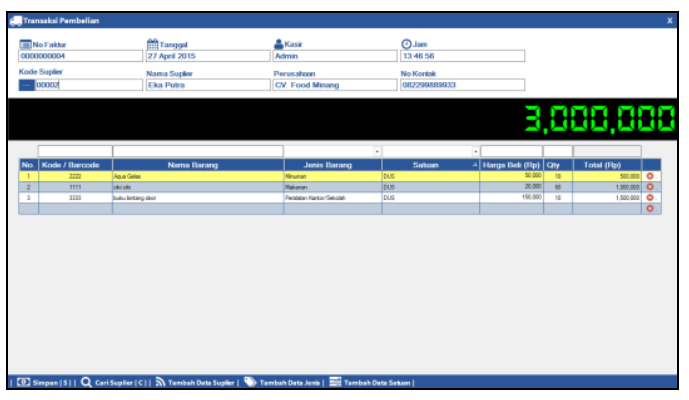

Gambar 4.15 Form Transaksi Pembelian

\subsubsection{Grafik Barang Terlaris Bulanan}

Grafik barang terlaris bulanan merupakan laporan dalam bentuk grafik untuk melihat jumlah barang laris terjual dalam satu bulan.

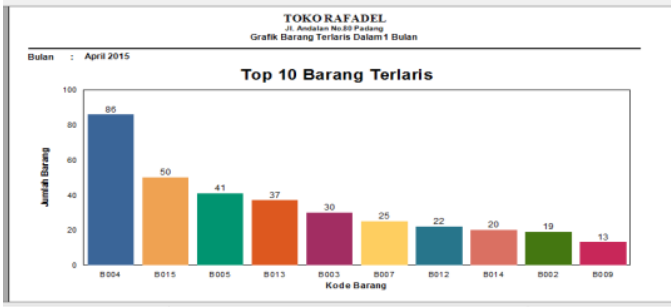

Gambar 4.16 Grafik Barang Terlaris Bulanan

\subsubsection{Grafik Barang Terlaris Tahunan}

Grafik barang terlaris bulanan merupakan laporan dalam bentuk grafik untuk melihat jumlah barang terlaris dalam satu tahun. 


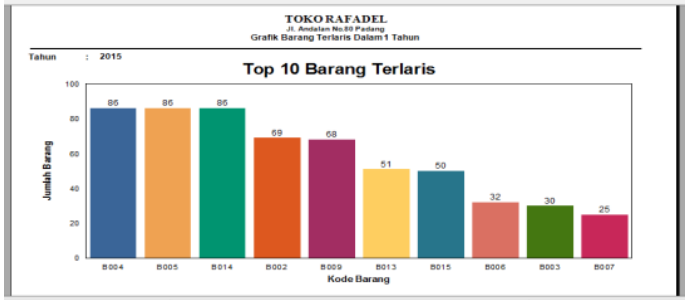

Gambar 4.17 Grafik Barang Terlaris Tahunan

\subsubsection{Grafik Penjualan Harian}

Grafik penjualan harian merupakan laporan dalam bentuk grafik dari penjualan harian.

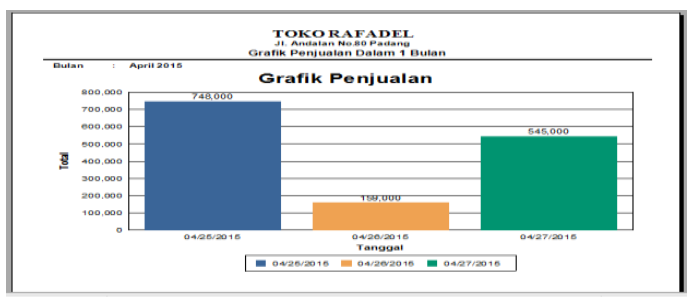

Gambar 4.18 Grafik Penjualan Harian

\subsubsection{Grafik Penjualan Bulanan}

Grafik penjualan bulanan merupakan laporan dalam bentuk grafik dari penjualan bulanan.

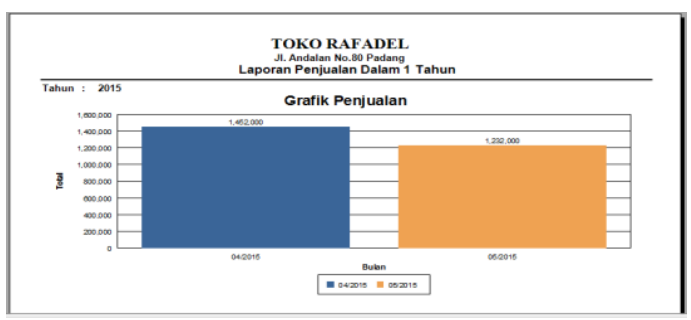

Gambar 4.19 Grafik Penjualan Bulanan

\subsubsection{Grafik Penjualan Tahunan}

Grafik penjualan Tahunan merupakan laporan dalam bentuk grafik dari penjualan tahuanan.

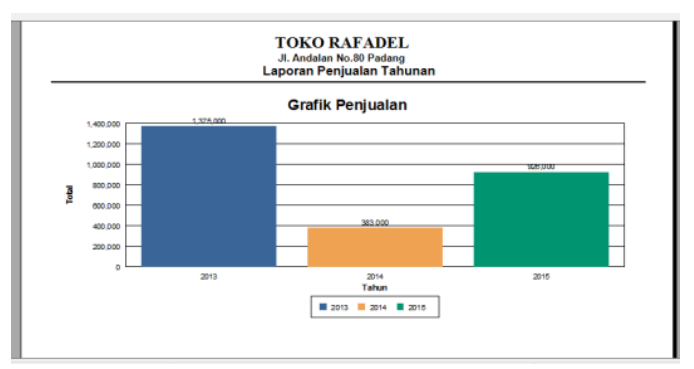

Gambar 4.20 Grafik Penjualan Tahunan

\subsubsection{Laporan Data Barang}

Laporan data barang merupakan laporan yang digunakan untuk mengecek stok barang.

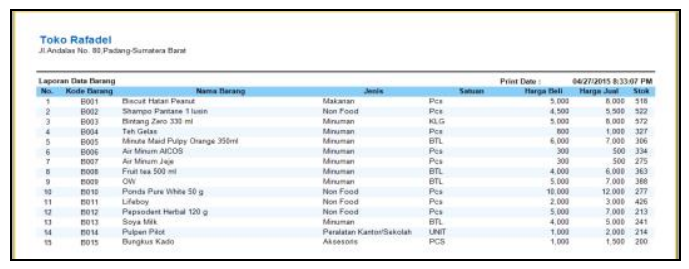

Gambar 4.21 Laporan Data Barang

\subsubsection{Laporan Data Suplier}

Laporan data suplier merupakan laporan yang digunakan untuk menampilkan keseluruhan data suplier.

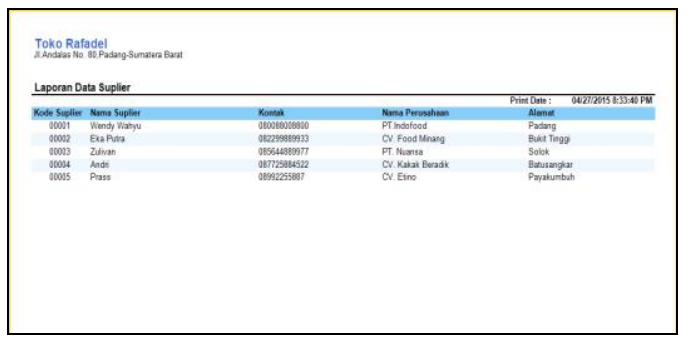

Gambar 4.22 Laporan Data Supplier

\subsubsection{Tampilan Laporan Penjualan Harian}

Laporan penjualan harian merupakan hasil penjualan yang ditampilkan dalam sehari.

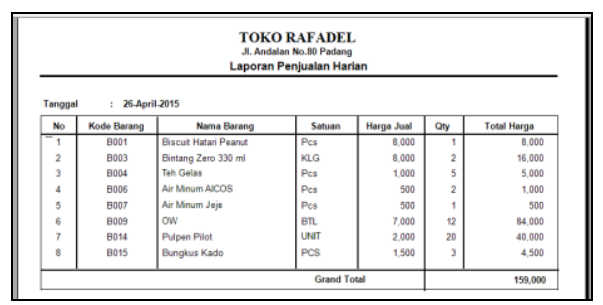

Gambar 4.23 Laporan Penjualan Harian

\subsubsection{Tampilan Laporan Penjualan Bulanan}

Laporan penjualan harian merupakan hasil penjualan yang ditampilkan dalam sebulan.

Gambar 4.24 Laporan Penjualan Bulanan

\subsubsection{Tampilan Laporan Penjualan Tahunan}

Laporan penjualan harian merupakan hasil penjualan yang ditampilkan dalam setahun. 


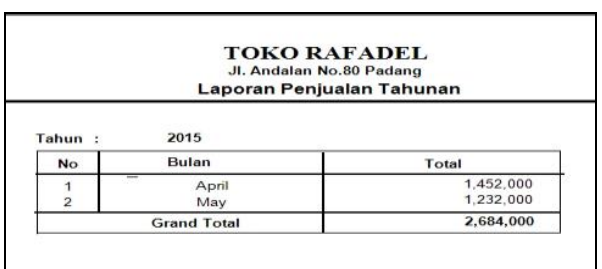

Gambar 4.25 Laporan Penjualan Tahunan

\subsubsection{Tampilan Laporan Pembelian Harian}

Laporan pembelian harian merupakan hasil pembelian yang ditampilkan dalam sehari.

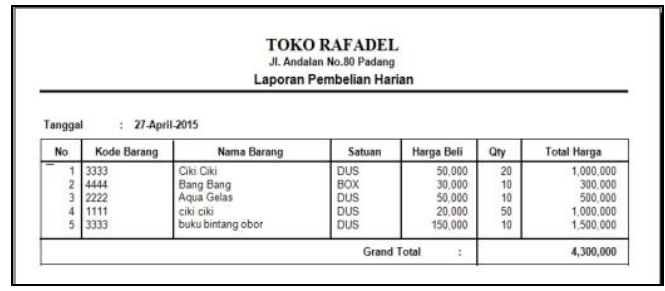

Gambar 4.26 Laporan Pembelian Harian

\subsubsection{Tampilan Laporan Pembelian Bulanan}

Laporan pembelian bulanan merupakan hasil pembelian yang ditampilkan dalam sebulan.

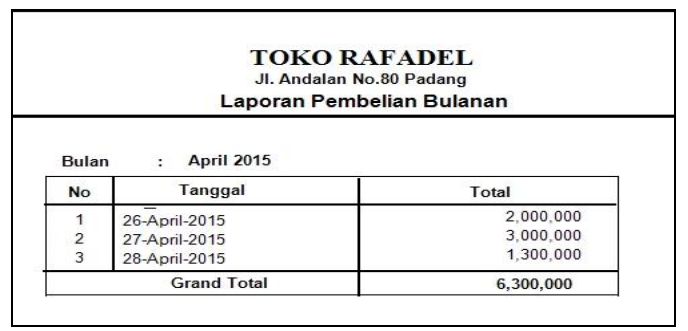

Gambar 4.27 Laporan Pembelian Bulanan

\subsubsection{Tampilan Laporan Pembelian Tahunan}

Laporan pembelian tahunan merupakan hasil pembelian yang ditampilkan dalam setahun.

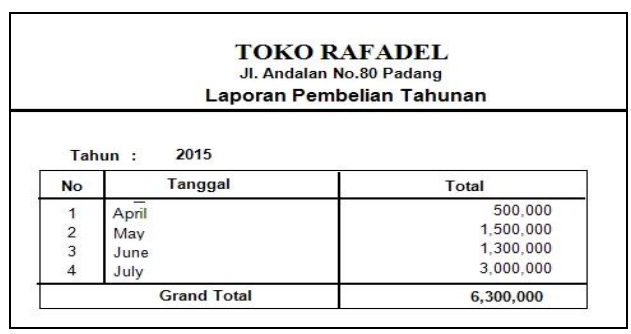

\section{PENUTUP}

Berdasarkan penjelasan dan pembahasan pada bab-bab sebelumnya maka dapat ditarik kesimpulan dan saran-saran yang dapat menunjang perbaikan sistem di masa yang akan datang.

\subsection{Kesimpulan}

Adapun kesimpulan yang dapat ditarik dari pembahasan skripsi ini adalah:

1. Dengan teknologi computer yang semakin mengglobal dikalangan masyarakat umum, memudahkan manusia untuk selalu berfikir dan bertindak secara efektif dan efisien.

2. Dengan penggunaan dan pemanfaatan sistem informasi berbasis komputer secara optimal maka akan menghasilkan suatu informasi yang tepat, cepat dan akurat.

3. Keuntungan dari penggunaan sistem informasi berbasis komputer dalam transaksi penjualan dan pembelian adalah memberikan informasi dan laporan yang cepat, tepat dan akurat.

4. Dengan adanya komputerisasi yang dilengkapi dengan Bahasa Pemrograman Microsoft Visual Basic.Net 2013 akan membantu dalam pengambilan keputusan yang cepat.

\subsection{Saran}

Berdasarkan kesimpulan diatas, maka dapat dikemukankan beberapa saran yang diharapkan akan membantu. Adapun saransaran yang diajukan adalah sebagai berikut :

1. Sistem manual yang lama tetap dijalankan secara paralel dengan sistem yang baru sambil melatih para karyawan sebagai pelaksana dari sistem yang baru, sehingga kasir dapat memahami penggunaan dari sistem yang diterapkan agar tidak terjadi kesalahan baik di dalam memasukkan data maupun penggunaan sistem.

2. Mengadakan training dalam mengoperasikan sistem yang baru.

3. Setelah dirasakan bahwa sistem yang baru dapat dioperasikan dengan baik dan kasir telah selesai melakukan training dan dapat mengoperasikan sistem tersebut maka sistem manual 
yang lama dapat digantikan dengan sistem yang baru secara keseluruhan.

4. Untuk melakukan pengolahan data yang baik hendaknya diciptakan suatu sistem kerja yang teratur, sehingga dapat memberikan informasi sesuai dengan apa yang diharapkan.

5. Perlu dilakukannya pemeliharaan atau perawatan terhadap sistem baik dari segi perangkat lunak maupun perangkat keras.

\section{DAFTAR PUSTAKA}

Enterprise, Jubile. 2015. Trik Cepat Menguasai MS SQL Server 2014. Jakarta: Elex Media

Hidayat, Dapai Ari. 2014. Rancang Bangun Aplikasi Point Of Sale (POS) Berbasis Web Dengan Pemanfaatan Trigger Pada Distribution Store CV.NMRQ.

Jogiyanto, HM. 2014. Pengenalan Sistem Informasi Edisi Revisi. Yogyakarta: Andi Ofset.

Jogiyanto, H.M. 2005. Analisys dan Desain. Yogyakarta: Andi Offset.

Jogiyanto, H.M. 2009. Sistem Teknologi Informasi. Yogyakarta: Andi Offset

Komputer, Wahana dan Team. 2012. Visual Basic 2010 Programming. Yogyakarta: Andi Offset.

Rossa, A.S dan Shalahuddin. M. 2011. Rekayasa Perangkat Lunak. Bandung: Modula.

Siska Andrian. “Analisa Dan Perancangan system informasi keuangan pada toko mitra sejati komputama Yogyakarta”. Yogyakarta. 2013

Sutabri, Tata. 2012. Konsep Sistem Informasi. Yogyakarta : Andi Offset.

Suryantara, I Gusti Ngurah, 2014. Perancangan Aplikasi dengan VB.Net 2013. Jakarta: Elex Media. 